\title{
INOVASI PEMBELAJARAN BLENDED LEARNING DENGAN METODE PROJECT BASED LEARNING TERHADAP MOTIVASI, MINAT DAN HASIL BELAJAR SISWA DI MASA PANDEMI COVID-19
}

\author{
lilis suryani' ${ }^{1}$, tri susilawati ${ }^{2}$, harjito ${ }^{3}$ \\ 1*Sekolah Pascasarjana Program Studi Manajemen Inovasi Universitas Teknologi Sumbawa \\ ${ }^{2}$ Fakultas Teknologi Dan Mineral Universitas Teknologi Sumbawa \\ ${ }^{3}$ Sekolah Pascasarjana Program Studi Manajemen Inovasi Universitas Teknologi Sumbawa
}

*Corresponding Author email:1 ${ }^{*}$ ilisumusahid@gmail.com, ${ }^{2}$ Tri.susilawati@uts.ac.id, 3harjito@uts.ac.id

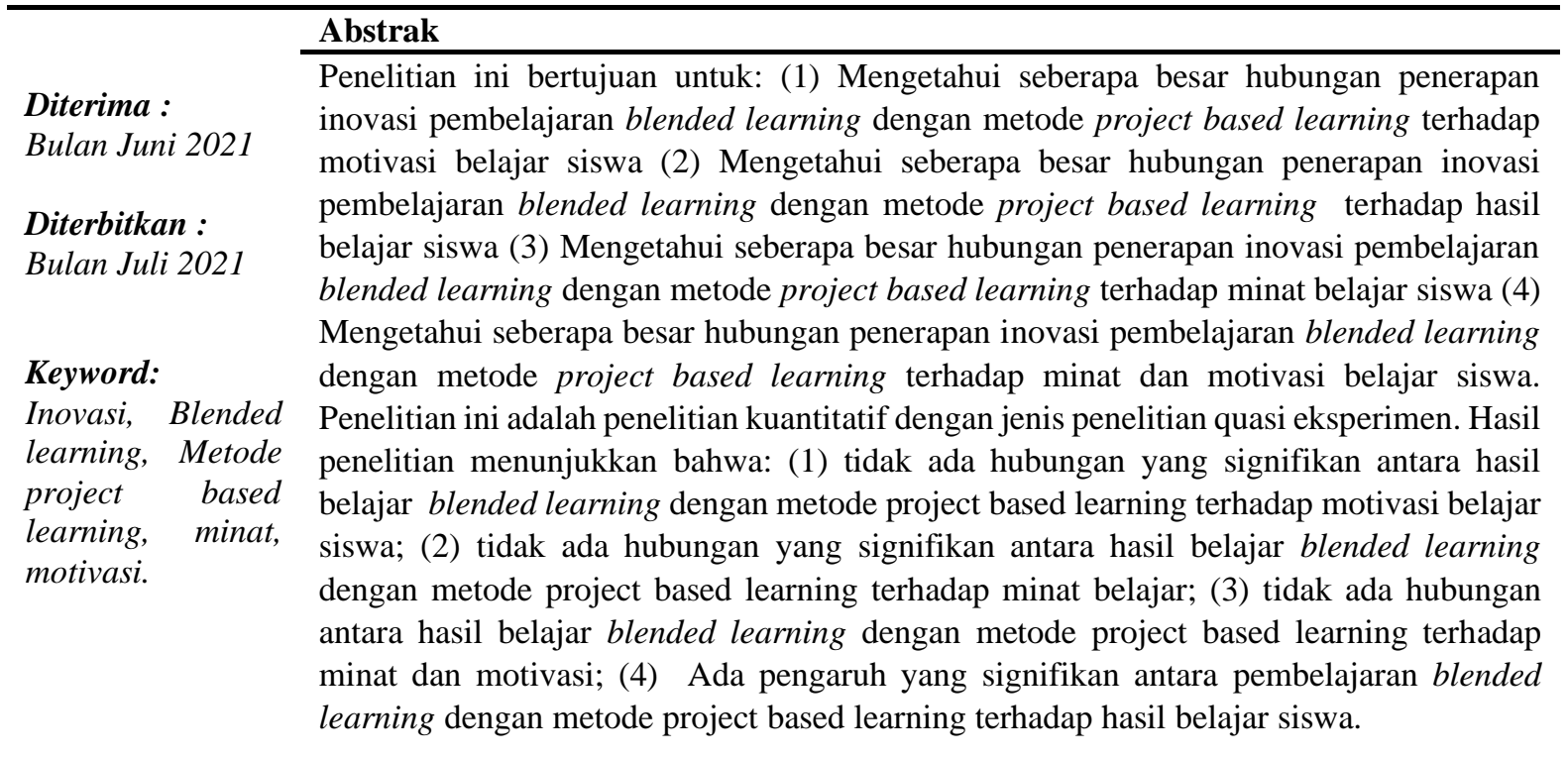

\section{PENDAHULUAN}

Wabah Covid-19 yang melanda dunia berdampak besar bagi sektor pendidikan, sekitar 180 negara memutuskan untuk menutup sementara sekolah-sekolah dan membiarkan sekitar 1,4 milyar anak tidak bersekolah (WeForum.org). Hal ini tentu menyebabkan siswa kehilangan kesempatan belajar. Penutupan sekolah-sekolah di Indonesia mulai dilakukan sejak akhir maret 2020, bertepatan dengan hari-hari terakhir pelaksanaan ujian sekolah kelas XII, sehingga ada beberapa mata pelajaran yang pelaksanaan ujiannya tidak bisa dilakukan secara langsung.

Mengingat begitu besarnya dampak penutupan sekolah bagi hak-hak anak untuk memperoleh pendidikan, Menteri Pendidikan Indonesia merespon dengan mengeluarkan beberapa kebijakan, yaitu :

1. SE Kemdikbud No. 3/ 2020 tentang pencegahan Covid-19 pada satuan pendidikan

2. SE Kemdikbud No 36962/MPK.A/HK/2020 tentang pembelajaran daring dan bekerja dari rumah.

3. SE Kemdikbud No. 4 /2020 tentang pelaksanaan kebijakan pendidikan dalam masa darurat penyebaran Covid-19
4. SE Kemdikbud No. 15 / 2020 tentang pedoman penyelenggaraan belajar dari rumah dalam masa darurat penyebaran Covid-19.

Dengan dikeluarkannya Surat Edaran Kemedikbud di atas, maka para siswa tetap dapat memperoleh hak-haknya untuk belajar, akan tetapi pelaksanaannya dari rumah atau disebut dengan istilah Belajar Dari Rumah (BDR). Tujuan BDR Berdaasarkan SE Kemdikbud No. 15 / 2020 ada dua yaitu :

1. Memastikan pemenuhan hak peserta didik untuk mendapatkan layanan pendidikan selama darurat Covid-19

2. Mencegah penyebaran dan penularan COVID-19 di satuan pendidikan.

Sedangkan prinsip pelaksanaan BDR adalah sebagai berikut :

1. Kegiatan BDR dilaksanakan untuk memberikan pengalaman belajar yang bermakna bagi peserta didik tanpa terbebani tuntutan penuntasan seluruh capaian kurikulum.

2. BDR dapat difokuskan pada pendidikan kecakapan hidup, antara lain mengenai pandemi COVID-19

3. Aktivitas dan penugasan selama BDR dapat bervariasi antar daerah, satuan pendidikan dan 
peserta didik sesuai minat dan kondisi masingmasing, termasuk mempertimbangkan kesenjangan akses terhadap fasilitas BDR.

Berdasarkan hasil survei BDR pada orangtua dan anak yang dilakukan Kemendikbud tahun 2020, diperoleh data bahwa $63,5 \%$ anak yang berada di daerah 3T (Tertinggal, Terdepan dan Terluar Indonesia) menyatakan kegiatan BDR yang dilakukannya tidak menyenangkan, 36,5\% menyatakan menyenangi kegiatan BDR. Sedangkan survey terhadap anak-anak di daerah bukan 3T menyatakan, 62,5\% menyenangi kegiatan BDR yang dilakukan, dan sisanya $37,5 \%$ tidak menyenangi kegiatan BDR yang dilakukannya. Jika dihitung secara nasional, maka diperoleh data $62,5 \%$ siswa tidak menyenangi kegiatan BDR dan 37,5\% menyenangi kegiatan BDR. Hasil Survey terhadap orangtua siswa mengenai tantangan BDR menyatakan bahwa 38,5\% kurang bimbingan guru, $35 \%$ akses internet tidak lancar, $7 \%$ tidak memiliki gawai yang memadai, $4 \%$ tidak bisa melakukan akses aplikasi belajar online, 3\% kurang pendampingan orangtua, $13 \%$ berasal dari hal-hal lainnya. BDR diidentikkan dengan siswa mengerjakan banyak tugas, kurangnya interaksi dari guru, kurangnya pendampingan orangtua atau jika dilakukan secara luring, BDR merepotkan dan membuat guru kelelahan karena harus bolak-balik ke rumah siswa satu per satu.

Tantangan BDR itu memerlukan inovasiinovasi pembelajaran yang tidak membebani siswa, orangtua siswa dan guru. Salah satu inovasi yang bisa dilakukan adalah dengan penerapan Blended learning dengan metode Project based learning yang terintegrasi. Melalui metode ini pembelajaran dapat dilakukan dengan dua cara baik daring maupun luring, beberapa guru dapat berkolaborasi memberikan satu proyek yang sama kepada siswa pada Kompetensi Dasar (KD) tertentu yang berkaitan tetapi dengan penilaian yang berbeda.

Mengambil pengalaman dari BDR selama 3 bulan terakhir (Maret - September 2020), bahwa pembelajaran daring dirasakan oleh banyak guru pada umumnya dan guru-guru di SMKN 3 Sumbawa khususnya, kurang efektif karena sedikitnya partisipasi siswa. Hal ini diketahui melalui laporan pembelajaran daring yang disusun oleh masing-masing guru mata pelajaran yang diserahkan kepada wakasek kurikulum. Para Guru mengeluhkan banyaknya persentase siswa yang tidak mengumpulkan tugas, setelah dilakukan penelusuran banyak alasan yang mendasari diantaranya beberapa siswa sulit dihubungi karena tinggal di daerah terluar sumbawa yang minim sinyal, beberapa siswa tidak memiliki gawai yang memadai untuk pembelajaran online, atau ada siswa yang memang tidak berniat mengumpulkan tugas tanpa alasan, artinya siswa tersebut kurang motivasi terhadap tugas-tugas yang diberikan. Keluhan yang sama juga dirasakan oleh peneliti selaku guru pengampu mata pelajaran Produk Kreatif dan Kewirausahaan (PK\&K) di kelas XII SMKN 3 Sumbawa Besar, sehingga peneliti termotivasi melakukan penelitian untuk mengatasi permasalahan-permasalahan yang muncul di kelas tersebut dan diajukanlah penelitian yang berjudul “ Inovasi Pembelajaran Blended learning Dengan Metode Project based learning Terhadap Motivasi dan Hasil Belajar Siswa di Masa Pandemi Covid19 "

Model pembelajaran Blended Learning dengan metode project based learning diharapkan dapat meningkatkan motivasi, minat dan hasil belajar peserta didik dalam situasi pandemik Covid19.

Penelitian ini diharapkan bermanfaat :

1. Bagi Guru : Menambah kekayaan dan inovasi pembelajaran yang membantu peningkatan minat dan motivasi belajar siswa.

2. Bagi Peneliti : Sebagai bahan rujukan atau referensi bagi yang ingin melakukan penelitian terkait metode pembelajaran blended learning.

3. Bagi Masyarakat : memberikan informasi tambahan terkait metode pembelajaran blended learning pada masa pandemic Covid-19.

4. Bagi Pemerintah : Sebagai bahan rujukan terkait system dan metode pembelajaran blended learning

\section{LANDASAN TEORI}

\section{Pembelajaran produk kreatif dan kewirausahaan (PK dan K)}

Mata pelajaran produk kreatif dan kewirausahaan adalah mata pelajaran yang terkait secara langsung dalam penanaman pendidikan kewirausahaan kepada siswa. Mata pelajaran tersebut dapat memberikan Pemahaman dan keterampilan berwirausaha kepada siswa. Selain pemberian materi dalam mata pelajaran produk kreatif dan kewirausahaan terdapat kegiatan berupa aktivitas praktik dalam menerapkan materi yang telah di pelajari.

Menurut Undang-Undang No. 20 tahun 2003 pasal 3 ayat 1 , pendidikan adalah usaha sadar dan terencana untuk mewujudkan suasana belajar dan proses pembelajaran agar peserta didik secara aktif mengembangkan potensi dirnya untuk memiliki kekuatan spiritual keagamaan, pengendalian diri, kepribadian, kecerdasan, ahlak mulia, serta keterampilan yang diperlukan dirinya, masyarakat, bangsa dan Negara. Sekolah merupakan tempat untuk menempuh pendidikan secara formal. Sekolah adalah tempat berlangsungnya kegiatan belajar mengajar dan tempat berinteraksi antara guru dan siswa. Di sekolah siswa dapat mengembangkan sikap, pengetahuan dan keterampilan yang di miliki. 
Salah satu usaha pemerintah untuk menanamkan pengetahuan berwirausaha adalah dengan memberikan pembelajaran kewirausahaan di sekolah.

Pada jenjang Sekolah Menengah Atas (SMA) mata pelajaran produk kreatif dan kewirausahaan ini dikenal dengan nama pelajaran Kewirausahaan, sedangkan pada jenjang SMK disebut sebagai pelajaran Produk kreatif dan Kewirausahaan. Kurikulum terbaru yang digunakan dalam pembelajaran PK dan K di SMK Negeri 3 Sumbawa Besar menggunakan kurikulum 2013 revisi 2018. Mata pelajaran ini diajarkan pada kelas XI dan XII .

\section{Blended learning}

Bersin (2004) mendefinisikan sebagai berikut "Blended learning is the combination of diferent training "media" (technologies, Activies, types of events) to create an optimum training program for term 'blended" means that traditional instructor-led training is being supplemented with other electronic formats. In the context of this book, blended learning program use many different forms of e-learning, perhaps complemented with instructor-led training and other liveformats".

Tujuan Blended learning adalah untuk mensintesis pembelajaran tatap muka dan pembelajaran berbasis online menjadi satu campuran yang terintegrasi sehingga dapat menciptakan dampak yang tinggi, efisien, dan menarik. Secara praktis, blended learning berarti bahwa pembelajaran (pembelajaran tatap muka dalam kelas) juga dilengkapi dengan format elektronik lainnya (e-learning) untuk membuat suatu program pembelajaran yang optimal.

Blanded adalah campuran, kombinasi yang baik dan learning merupakan proses pembelajaran yang memanfaatkan berbagai macam aktivitas dan media baik secara fisik maupun maya. Berikut adalah aktivitas yang ada pada Blended learning:

a. Pertemuan secara langsung di ruang kelas (pembelajaran tatap muka).

b. Pembelajaran secara online seperti tatap muka melalui aplikasi google meeting, zoom, cisco webex, dll).

c. E-learning (kegiatan pembelajaran dengan memanfaatkan software pengelolaan konten pembelajaran seperti : google classroom, ruangguru, edmodo dll).

d. Blended Learning yaitu mencampur kegiatan tatap muka langsung dengan pembelajaran online memanfaatkan teknologi seperti sms, mms atau media sosial : facebook, whatsapp, telegram, youtube dll. e. Proses pembelajaran Blended learning harus menyesuaikan kondisi yang disepakati semua pihak agar dapat diterapkan sccara efektif.

\section{Project based learning (Pembelajaran Berbasis Proyek)}

Pembelajaran berbasis proyek merupakan pengorganisasian proses belajar yang dikaitkan dengan suatu objek konkret yang dapat ditinjau dari berbagai disiplin keilmuan atau mata pelajaran (BSNP, 2007:32). Menurut Djamarah dan Zain (2006:83) metode proyek adalah cara penyajian pelajaran yang bertitik tolak dari suatu masalah, kemudian dibahas dari berbagai segi yang berhubungan sehingga pemecahannya secara keseluruhan dan bermakna . Dalam proses pembelajaran, pemecahan suatu masalah tidaklah tuntas apabila hanya ditinjau dari satu disiplin ilmu saja, melainkan dipandang dari berbagai disiplin ilmu atau mata pelajaran yang berkaitan dan memberikan sumbangsih terhadap penyelesaian masalah tersebut. Blumenfeld et al. (dalam Kamdi, 2008:4) mendeskripsikan metode pembelajaran berbasis proyek (project based learning ) berpusat pada proses relatif berjangka waktu, berfokus pada masalah, unit pembelajaran bermaknadengan mengintegrasikan konsep-konsep dari sejumlah komponen pengetahuan atau disiplin atau lapangan studi.

Tidak semua kegiatan belajar aktif dan melibatkan proyek dapat disebut pembelajaran berbasis proyek. Oleh sebab itu, Thomas (dalam Kamdi, 2008:10) menyatakan terdapat 5 kriteria agar suatu pembelajaran dapat digolongkan dalam pembelajaran berbasis proyek, yaitu : Keterpusatasn (centrality), berfokus pada pertanyaan atau masalah, investigasi konstruktif atau desain, otonomi pembelajar, dan realisme.

\section{MATODE PENELITIAN}

\section{Tempat dan waktu pelaksanaan penelitian}

Penelitian ini dilakukan selama 3 bulan sejak tanggal yaitu sejak tanggal 25 Juli 2020- 24 Oktober 2020, berpusat di SMKN 3 Sumbawa Besar dan dalam pelaksanaannya bisa dilakukan di rumah masing-masing atau tempat lain yang dibutuhkan.

\section{Desain Penelitian}

Penelitian ini adalah penelitian kuantitatif dengan jenis penelitian quasi eksperimen. Populasinya adalah seluruh siswa kelas XII SMK Negeri 3 Sumbawa Besar tahun Pelajaran 2020/2021 yang berjumlah 700 Siswa. Teknik pengambilan sampel dipilih menggunakan non probability sampling. menggunakan teknik sampling purposive. 
Teknik pengambilan sampel dengan cara purposive sampling adalah teknik pengambilan sampel dengan pertimbangan tertentu, (Sugiono 2016:67). Yang menjadi sampel dalam penelitian ini adalah XII TB (Tata Busana), dengan pertimbangan karena kelas tersebut yang diampu pelajaran produk kreatif dan kewirausahaan oleh peneliti sendiri dan nilai rata-rata kelas terendah dari 3 kelas yang diajarkan peneliti menggunakan metode project based learning.

Peneliti melibatkan 4 variabel yaitu 1 variabel independen (bebas) dan 3 variabel dependen (terikat). Variabel independen atau disebut juga variabel bebas adalah variabel yang mempengaruhi atau yang menjadi sebab perubahannya atau timbulnya variabel dependen (terikat), (Sugiyono, 2016:4). Inovasi pembelajaran blended learning dengan metode project based learning merupakan variabel bebas dalam penelitian ini. Sedangkan variabel dependen (terikat) adalah variabel yang dipengaruhi atau yang menjadi akibat karena adanya variabel bebas, (Sugiyono, 2016:4). Hasil belajar, minat dan motivasi belajar siswa adalah variabel dependen dalam penelitian ini.

Pengumpulan data pada penelitian ini dilakukan melalui tes dan angket. Data yang berkaitan dengan hasil belajar siswa dikumpulkan melalui tes (pretes dan postes). Pretes diberikan sebelum peneliti memberi perlakuan pembelajaran di kelas sampel penelitian, dengan tujuan untuk mengetahui kemampuan awal siswa. Postes diberikan setelah seluruh rangkaian kegiatan pembelajaran di kelas dilaksanakan. Dari hasil pretes dan postes tersebut dihitung skornya.

\section{Diagram alir pelaksanaan penelitian}

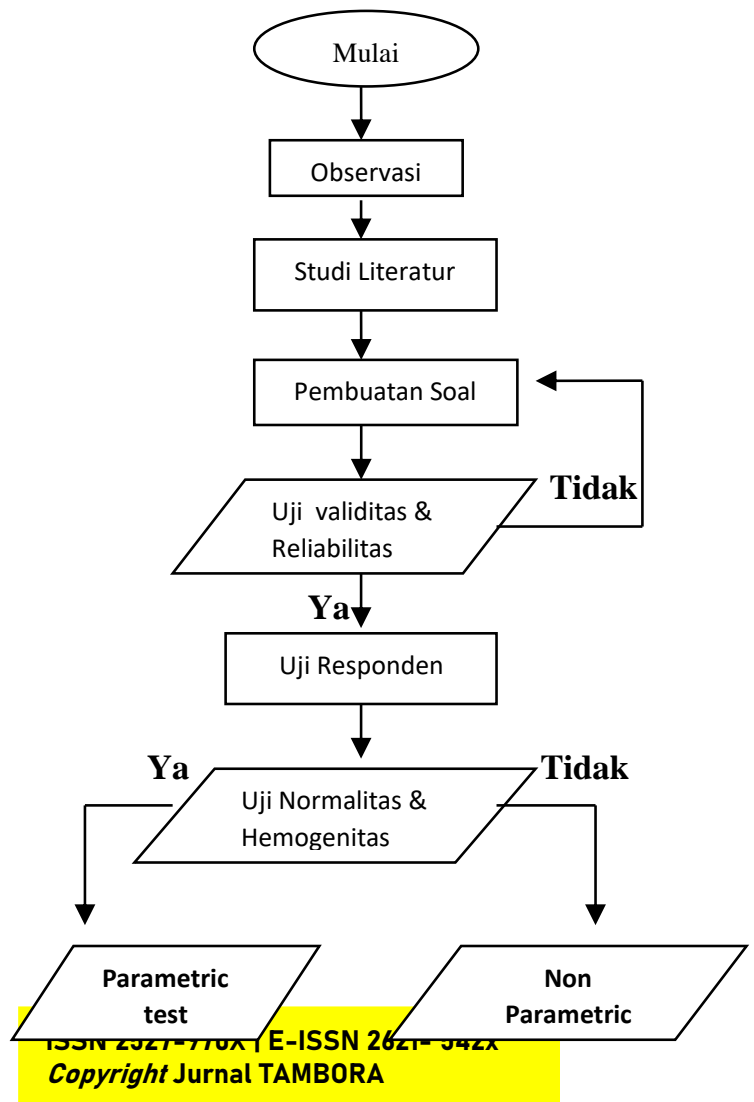

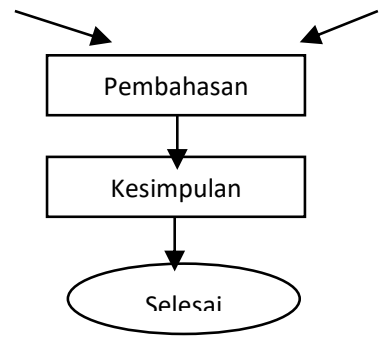

\section{HASIL DAN PEMBAHASAN}

Proses penelitian dilakukan selama tiga bulan atau dua belas kali pertemuan (6 kali pertemuan daring dan 6 kali pertemuan blended) .

\section{Pembelajaran Online}

Proses penelitian pada kelas online dimulai pada tanggal 25 Juli 2020 sampai tanggal 12 september 2020. Pembelajaran online dilakukan melalui google classroom (GC), whatsapp (WA) dan google meeting. Jadwal pembelajaran daring untuk mata pelajaran PK dan K jatuh pada hari sabtu setiap pekannya di kelas XII Tata Busana. Kelas XII Tata Busana terdiri dari 23 siswa yang semuanya perempuan.

\section{Pembelajaran Blended}

Pertemuan pertama pada pembelajaran blended dimulai dengan pembelajaran simulasi tatap muka yaitu pada tanggal 5 Oktober tahun 2020. Pembelajaran dilakukan di kelas XII Tata Busana setiap hari kamis mulai pukul 07.30 - 10.30 WITA. Pada pertemuan ini siswa diminta mengerjakan soal pretest dan membaca $E$-Modul mengenai materi perakitan produk.

Pertemuan kedua pada pembelajaran blended learning ini bertepatan dengan diijinkan kembali sekolah melakukan pembelajaran tatap muka pertama di SMKN 3 Sumbawa besar yaitu pada tanggal 12 Oktober 2020. Di pertemuan kedua ini peneliti memberikan tugas proyek kepada siswa, siswa diminta membuat kelompok yang terdiri dari 3 orang perkelompok, setiap kelompok diminta mempraktikkan cara merakit dynamo mesin jahit pada mesin jahit manual dan kemudian diuji kelayakannya. Tugas dikumpulkan dalam bentuk video tutorial dan dikirimkan melalui WA.

Adapun hasil pretest dan posttest adalah sebagai berikut:

Tabel 4.1.Paired Samples Statistics

\begin{tabular}{|c|c|c|c|c|c|}
\hline & & Mean & $\mathrm{N}$ & $\begin{array}{c}\text { Std. } \\
\text { Deviati } \\
\text { on } \\
\end{array}$ & $\begin{array}{c}\text { Std. } \\
\text { Error Mean } \\
\end{array}$ \\
\hline \multirow{2}{*}{$\begin{array}{l}\text { Pair } \\
1\end{array}$} & Pretest & 40.04 & 23 & 8.025 & 1.673 \\
\hline & Posttest & 51.78 & 23 & 10.617 & 2.214 \\
\hline
\end{tabular}


Nilai rata-rata sebelum diterapkan pembelajaran blended learning dengan metode project based learning yaitu 40,04 artinya masih jauh dari criteria ketuntasan minimal (KKM) yaitu 75. Setelah diberikan perlakuan terjadi peningkatan sebesar 29,32 \% menjadi 51,78. Namun, hasil tersebut masih dikategorikan belum tuntas.

\section{Analisis Data}

Rumusan masalah ini menggunakan uji paired sample t-test sebagai dasar pengambilan keputusan. Syarat yang harus dipenuhi untuk melakukan uji ini adalah data yang terdistribusi normal. Uji normalitas data menghasilkan data sebagaimana tertulis dalam Tabel 4.4 berikut. :

\section{Tabel 4.4 One-Sample Kolmogorov-Smirnov} Test

\begin{tabular}{llr} 
& & \multicolumn{1}{c}{$\begin{array}{c}\text { Unstandard } \\
\text { ized } \\
\text { Residual }\end{array}$} \\
\hline $\mathrm{N}$ & Mean & 23 \\
\cline { 2 - 3 } $\begin{array}{l}\text { Normal } \\
\text { Parameters }\end{array}$ & Std. Deviation & 7.88653037 \\
\hline Most Extreme & Absolute & .174 \\
\cline { 2 - 3 } Differences & Positive & .123 \\
\cline { 2 - 3 } & Negative & -.174 \\
\hline Test Statistic & & .174 \\
\hline Asymp. Sig. (2-tailed) & $.069^{c}$ \\
\hline \multicolumn{1}{c}{ Uji normalitas dengan } & menggunakan
\end{tabular}
metode kolmogrov smirnov menghasilkan nilai signifikansi 0,069 lebih besar dari 0,05 yang berarti data terdistribusi normal. Karena data yang sudah terdistribusi normal artinya uji paired sample t-test dapat dilakukan.

\subsection{Hubungan antara hasil belajar blended learning dengan metode project based learning terhadap motivasi belajar siswa}

Rumusan masalah yang pertama adalah untuk mengetahui bagaimana hubungan antara hasil belajar blended learning dengan metode project based learning terhadap motivasi belajar siswa. Untuk membantu menyimpulkan hasil maka diperlukan hipotesis statistik sebagai berikut :

Ho : Ada hubungan yang signifikan antara hasil belajar blended learning dengan metode project based learning terhadap motivasi belajar siswa.

$\mathrm{H}_{1} \quad$ : Tidak ada hubungan yang signifikan antara hasil belajar blended learning dengan metode project based learning terhadap motivasi belajar siswa.

Adapun hasil dari SPSS adalah tertulis dalam table 4.5. berikut :

Tabel 4.5. Correlations

\begin{tabular}{|c|c|c|c|}
\hline & & Posttest & Motivasi \\
\hline \multirow[t]{3}{*}{ Posttest } & $\begin{array}{l}\text { Pearson } \\
\text { Correlation }\end{array}$ & 1 & -.229 \\
\hline & Sig. (2-tailed) & & .292 \\
\hline & $\mathrm{N}$ & 23 & 23 \\
\hline \multirow[t]{3}{*}{ Motivasi } & $\begin{array}{l}\text { Pearson } \\
\text { Correlation }\end{array}$ & -.229 & 1 \\
\hline & Sig. (2-tailed) & .292 & \\
\hline & $\mathrm{N}$ & 23 & 23 \\
\hline
\end{tabular}

Kesimpulan isi Tabel 4.5: nilai Signifikansi menunjukkan 0,292 lebih besar dari nilai 0,05 yang dapat disimpulkan bahwa $\mathrm{H}_{0}$ ditolak artinya tidak ada hubungan yang signifikan antara metode pembelajaran blended learning dengan motivasi belajar siswa. Nilai koefesien korelasi yang negative $(-0,292)$ menunjukkan hubungan antara metode pembelajaran dengan motivasi saling bertolak belakang atau jika peningkatan hasil belajar meningkat maka motivasi belajar menurun begitu pula sebaliknya.

Hasil penelitian ini berbeda dengan penelitian dari Lilik Handayani guru SMP Negeri 4 Gunungsari, Kabupaten Lombok Barat. Penelitan dengan judul Peningkatan Motivasi Belajar IPA Melalui Metode Pembelajaran Project based learning pada Masa Pandemi Covid-19 bagi Siswa SMP Negeri 4 Gunungsari menyimpulkan bahwa ada peningkatan motivasi siswa dalam belajar IPA dengan menggunakan metode Project Based learning.

3.2. Hubungan antara hasil belajar blended learning dengan metode project based learning dengan minat belajar.

Rumusan masalah yang kedua adalah untuk mengetahui bagaimana hubungan antara hasil belajar blended learning dengan metode project based learning terhadap minat belajar siswa. Untuk membantu menyimpulkan hasil maka diperlukan hipotesis statistic sebagai berikut :

Ho : Ada hubungan yang signifikan antara hasil belajar blended learning dengan metode project based learning terhadap minat belajar siswa. $\mathrm{H}_{1} \quad$ : Tidak ada hubungan yang signifikan antara hasil belajar blended learning dengan metode project based learning terhadap minat belajar siswa. Adapun hasil dari SPSS adalah tertulis dalam Tabel 4.6 berikut :

Tabel 4.6 Correlations

\begin{tabular}{lll|l} 
& \multicolumn{2}{c}{$\begin{array}{c}\text { Postt } \\
\text { est }\end{array}$} & Minat \\
\hline Posttest & $\begin{array}{l}\text { Pearson } \\
\text { Correlation }\end{array}$ & 1 & -.119 \\
& $\begin{array}{lll}\text { Sig. (2-tailed) } \\
\text { Minat }\end{array}$ & \multicolumn{1}{l}{.590} \\
& $\mathrm{~N}$ & 23 & 23 \\
\hline & $\begin{array}{l}\text { Pearson } \\
\text { Correlation }\end{array}$ & -.119 & 1 \\
\hline
\end{tabular}


Sig. (2-tailed) .590

$\mathrm{N} \quad 23 \quad 23$

Kesimpulan isi Tabel 4.6 : nilai Signifikansi menunjukkan 0,590 lebih besar dari nilai 0,05 yang dapat disimpulkan bahwa tidak ada hubungan yang signifikan antara metode pembelajaran blended learning dengan minat belajar siswa. Nilai koefesien korelasi yang negative $(-0,119)$ menunjukkan hubungan antara metode pembelajaran dengan minat saling bertolak belakang atau jika peningkatan hasil belajar meningkat maka minat belajar menurun begitu pula sebaliknya.

3.3. Hubungan antara penerapan blended learning dengan metode project based learning terhadap minat dan motivasi belajar siswa

Rumusan masalah yang ketiga adalah untuk mengetahui bagaimana hubungan antara penerapan blended learning dengan metode project based learning terhadap minat dan motivasi belajar siswa. Untuk membantu menyimpulkan hasil maka diperlukan hipotesis statistik sebagai berikut :

Ho : Ada hubungan yang signifikan antara penerapan blended learning dengan metode project based learning terhadap minat dan motivasi belajar siswa.

$\mathrm{H}_{1} \quad$ : Tidak ada hubungan yang signifikan antara penerapan blended learning dengan metode project based learning terhadap minat dan motivasi belajar siswa.

Adapun hasil dari SPSS adalah tertulis dalam table 4.7 berikut :

\subsubsection{Pengaruh pembelajaran blended learning} dengan metode project based learning terhadap hasil belajar siswa

Rumusan masalah yang keempat adalah untuk mengetahui bagaimana pengaruh pembelajaran blended learning dengan metode project based learning terhadap hasil belajar siswa. Untuk membantu menyimpulkan hasil maka diperlukan hipotesis statistic sebagai berikut :

Ho : Ada pengaruh yang signifikan antara pembelajaran blended learning dengan metode project based learning terhadap hasil belajar siswa.

$\mathrm{H}_{1} \quad$ : Tidak ada pengaruh yang signifikan antara hasil belajar blended learning dengan metode project based learning terhadap hasil belajar siswa.

Adapun hasil dari SPSS adalah tertulis dalam Tabel 4.8 berikut :

\section{Tabel 4.8 Paired Samples Test}

Paired Differences $\quad \mathrm{t} \quad \mathrm{df}$

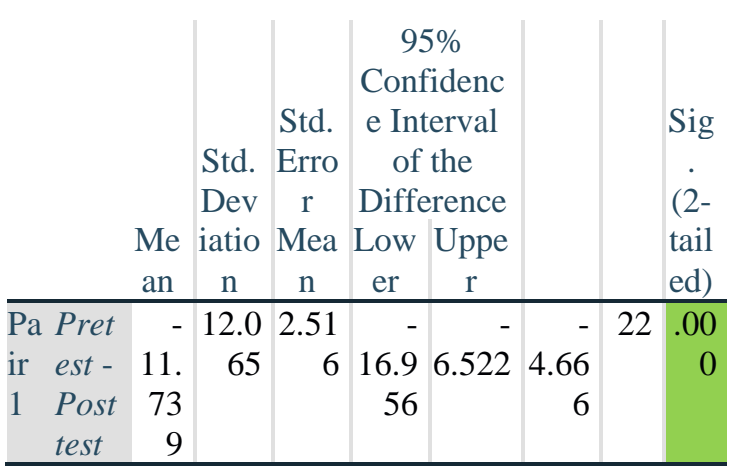

Pengambilan keputusan berdasarkan nilai signifikansi output SPSS yang menunjukan nilai 0,000 atau lebih kecil dari 0,05 yang dapat disimpulkan bahwa terdapat perbedaan yang signigikan antara hasil belajar sebelum penerapan blended learning dengan setelah penerapan blended learning. Hal ini terlihat pula dari rata-rata hasil belajar sebelum dan setelah penerapan blended learning pada Tabel 4.1 yang mengalami peningkatan yaitu 40,4 menjadi 51,78 meskipun rata-rata tersebut belum mencapai standar KKM.

Hasil penelitian ini sejalan dengan penelitian Eka Rismayawati (2020, guru SMKN 1 Surabaya, penelitian dengan judul Penerapan Metode Pembelajaran Based Project untuk Meningkatkan Hasil Belajar Produk Kreatif dan Kewirausahaan Materi Desain Produk ini menyatakan bahwa Penerapan pembelajaran dengan metode berbased project memberikan peningkatatan yang lebih baik pada perolehan hasil belajar desain produk daripada penerapan pembelajaran dengan metode lainnya.

Tabel 4.7. Model Summary

\begin{tabular}{|c|c|c|c|c|c|c|c|c|}
\hline \multirow[b]{2}{*}{ M } & \multirow[b]{4}{*}{$\mathrm{R}$} & \multirow{3}{*}{$\begin{array}{l}\text { Adj } \\
\text { uste }\end{array}$} & \multirow{3}{*}{$\begin{array}{l}\text { Std. } \\
\text { Error }\end{array}$} & \multicolumn{5}{|c|}{ Change Statistics } \\
\hline & & & & $\mathrm{R}$ & & & & \\
\hline $\mathrm{o}$ & & & & Squ & $\mathrm{F}$ & & & Sig. \\
\hline d & & d R & of the & are & $\mathrm{Ch}$ & & & $\mathrm{F}$ \\
\hline e & Squ & Squ & Estim & Cha & an & & & Cha \\
\hline $1 \mathrm{R}$ & are & are & ate & nge & ge & df1 & df2 & nge \\
\hline 1.229 & .053 & $\begin{array}{l}. \\
.042\end{array}$ & 10.838 & .053 & $\begin{array}{l}.55 \\
6\end{array}$ & 2 & 20 & .582 \\
\hline
\end{tabular}

Keputusan diambil berdasarkan nilai Sig. F Change yang bernilai 0,582 atau lebih besar dari 0,05 . Artinya nilai tersebut menyatakan tidak ada hubungan yang signifikan antara minat dan motivasi siswa pada metode blended learning. Derajat hubungan antara minat dan motivasi dapat terlihat dari nilai koefesien $r$ yang menunjukkan angka 0,229 yang berarti hubungan sangat lemah.

Dengan kata lain dapat diinterpretasikan bahwa penerapan pembelajaran dengan metode berbased project dapat meningkatkan perolehan hasil belajar siswa pada materi desain produk daripada dengan metode pembelajaran lainnya. 
Lyna Latifah dan Nurdian Susilawati, dalam penelitiannya " Inovasi pembelajaran berbasis blended learning " menyimpulkan bahwa Perpaduan antara pendekatan pembelajaran cooperative learning dan blended learning tidak saja hanya membekali mahasiswa kemampuan memahami materi, namun lebih dari itu dapat meningkatkan kemampuan komunikasi dan keterampilan interpersonal, pemecahan masalah, analisis kritis dan keterampilan lain yang dibutuhkan sebagai lulusan akuntansi. Dengan kemudahan teknologi, keterbatasan pertemuan di kelas dapat dipecahkan dengan blended learning. Blended learning tidaklah sesederhana sebagai sebuah sebuah kombinasi pengajaran langsung (face to face) dan pengajaran online tapi lebih daripada itu sebagai elemen dari interaksi sosial, ketika para siswa diperlukan untuk lebih sering bekerjasama secara online, mereka saling berbagi permasalahan secara umum pada tingkatan yang beragam, mereka kemudian menciptakan komunitas "penyelesaian masalah" mereka sendiri.

Kurniawana Arizona juga menyimpulkan dalam penelitiannya "Pembelajaran online berbasis proyek salah satu solusi kegiatan belajar mengajar di tengah pandemi Covid-19, Penelitian ini menyatakan bahwa salah satu pendekatan pembelajaran yang dapat mengoptimalkan pembelajaran online adalah pembelajaran berbasis proyek. Pembelajaran ini memfasilitasi peserta didik untuk mempelajari konsep secara mendalam dan dapat meningkatkan hasil belajar.

Dari penelitian-penelitian terdahulu tersebut, diperoleh kesimpulan yang hampir sama dengan penelitian ini yaitu dalam hal peningkatan hasil belajar, penggunaan blended learning dengan metode project based learning mempunyai pengaruh yang signifikan atau dengan kata lain dapat meningkatkan hasil belajar siswa. Sedangkan dalam hal motivasi dan minat belajar siswa, penelitian ini memberikan hasil yang berbeda, dimana minat dan motivasi tidak dipengaruhi oleh system ataupun metode belajar.

\section{PENUTUP}

\section{Kesimpulan}

Berdasarkan hasil penelitian, dapat ditarik

kesimpulan sebagai berikut :

a. Motivasi belajar siswa tidak dipengaruhi oleh metode blended learning

b. Hasil belajar siswa tidak dipengaruhi oleh minat belajar.

c. Hasil belajar siswa tidak dipengaruhi oleh minat dan motivasi siswa d. Pembelajaran blended learning dengan metode project based learning dapat meningkatkan hasil belajar siswa

\section{Saran}

a. Jika system blended learning akan digunakan sepenuhnya perlu difikirkan mengenai fasilitas pendukung agar kendala teknis tidak terjadi selama proses pembelajaran dan factor-faktor penghambat pada pembelajaran daring dapat diminimalisir misalnya buruknya signal internet, gawai yang tidak memadai dan lainlain.

b. Dukungan dari pihak sekolah ataupun pemerintah terhadap peningkatan kompetensi guru di bidang teknologi guna mendukung kelancaran proses pembelajaran secara daring maupun luring.

c. Dukungan orangtua dan lingkungan sekitar sangat dibutuhkan dalam rangka membantu memotivasi dan meningkatkan minat belajar siswa

d. Penelitian ini masih belum sempurna, karena keterbatasan waktu dan biaya sehingga diharapkan bagi peneliti lain dapat menambahkan variabel control agar hasil lebih maksimal, misalnya faktor lingkungan, kebiasaan dan lain-lain.

\section{REFERENSI}

Arizona, Kurniawan, (2020), Pembelajaran online berbasis proyek salah satu solusi kegiatan belajar mengajar di tengah pandemi Covid19, Jurnal Ilmiah Profesi Pendidikan. 5(1) hal 64-70.

Barbie, Earl., 1986, The Practice of Social Research, Fourth Edition, California : Wadsworth publishing Co

Barroso. J. \& Cabranes, Gomez. 2000. Face to face Learning Methodelogies vs Distance Meaning Methodologies: Case Study Online using Qualitive Analysis. International Conference Of Multimedia and ICT in Education

Bersin, Josh. 2004. The Blended Bearning BookBest Bractices, proven Methodologies, and Lesson Learned. San fransisco: Pfeiffer

BNSP. (2006). Standar Isi untuk Satuan Pendidikan Dasar dan Menengah. Jakarta.

Harding, A., Kaczynski, D. \& Wood, L.N. (2005). Evaluation of Blended learning: Analysis of Quantitative Data, Uni Serve Science Blended learning Symposium

Proceedings:56-72

Hakim and A. B. Hakim, (2016). Efektifitas Penggunaan ELearning Moodle. Google Classroom Dan Edmodo. Jurnal IStatement Stimik ESQ.. 1(2), 1-6. 
Handayani, Lilik., 2020, Motivasi Belajar IPA Melalui Metode Pembelajaran Project based learning pada Masa Pandemi Covid19 bagi Siswa SMP Negeri 4 Gunungsari Lilik Handayani SMP Negeri 4 Gunungsari, Kabupaten Lombok Barat, Journal Paedagogis, 7(3), hal. 168-174. Diakses 25 Juli 2020 pukul 10:47 WITA.

Jamaluddin, D., Ratnasih, T., Gunawan, H., \& Paujiah, E. (2020). Pembelajaran daring masa pandemik Covid-19 pada calon guru: hambatan, solusi dan proyeksi. LP2M.

Johnsoon, D. and Johnson, R. 1994. Learning together an alone, cooperative and competitive and individualistic learning. Needham Height, MA: Prentice- Hall.

Latifah, Lyna., Susilowati, Nurdiana., 2011, Jurnal Pendidikan Ekonomi Dinamika Pendidikan, 4(2), hal.. 222-232. Diakses tannggal 9 november 2019 pukul 13:07 WITA

Lexy J. Moleong. Metodologi Penelitian Kualitatif, cet. 38 (Bandung: Remaja Rosdakarya, 2018)

Mathew B. Miles dan A. Michael Huberman, Analisis Data Kualitatif, alih bahasa Tjetjep Rohaendi Rohidi (Jakarta: Universitas Indonesia (UI Press), 1992)

Means, B., Toyama, Y., Murphy, R., \& Baki, M. (2013). The Effectiveness of Online and Blended Learning: A Meta-Analysis of the Empirical Literature. Teachers College Record, 115(3), 1-47.

Müller, C., Stahl, M., Alder, M., \& Müller, M. (2018). Learning Effectiveness and Students' Perceptions in a Flexible Learning Course. European Journal of Open, Distance and E-Learning, 21(2), 44-52.

Rismawati, Eka (2020), Penerapan Metode Pembelajaran Based Project untuk Meningkatkan Hasil Belajar Produk Kreatif dan Kewirausahaan Materi Desain Produk, Journal Of Education Action Research, 4
(1), hal. 62-70. Diakses 28 mei 2020 pukul 07:23.

Sugiyono., 2016, Metode Penelitian Pendidikan Pendekatan Kuantitatif, Kualitatif, dan $R$ dan D, cetakan 23, Bandung : Alfabeta

Sugiyono., 2016, Statistika Untuk Penelitian, cetakan 27, Bandung : Alfabeta

Surat Keputusan Bersama Empat Kementerian tentang Panduan Penyelenggaraan Pembelajaran pada Tahun Ajaran dan Tahun Akademik Baru di Masa Pandemi Covid-19.

SE Kemdikbud No. 3/ 2020 tentang pencegahan Covid-19 pada satuan pendidikan

SE Kemdikbud No 36962/MPK.A/HK/2020 tentang pembelajaran daring dan bekerja dari rumah.

SE Kemdikbud No. 4 /2020 tentang pelaksanaan kebijakan pendidikan dalam masa darurat penyebaran Covid-19

SE Kemdikbud No. 15 / 2020 tentang pedoman penyelenggaraan belajar dari rumah dalam masa darurat penyebaran

Surat Edaran Nomor : 420/3266.UM/Dikbud Tentang Layanan Pembelajaran Tahun Ajaran 2020/2021

\section{Internet}

https://farmasetika.com/2020/03/12/resmi-whoumumkan-wabah-Covid-19-sebagai-pandemik/ diakses hari kamis 9/7/2020 pukul 8.48).

https://nasional.kompas.com/read/2020/04/13/1810 1841/presiden-jokowi-teken-keppres-tetapkanwabah-Covid-19-bencana-nasional. ( diakses hari kamis 9/7/2020 pukul 09.02) 